\title{
NOVA GAZETA RENANA: A POLÍTICA EM SUA DIMENSÃO NEGATIVA NO PENSAMENTO DE MARX
}

\author{
NUEVA GACETA RENANA: LA POLÍTICA EN SU DIMENSIÓN NEGATIVA EN EL PENSAMIENTO \\ DE MARX
}

\author{
Fátima Maria Nobre Lopes* \\ Adauto Lopes da Silva Filho**
}

\section{RESUMO}

Este texto em si não discorre sobre a concepção da política em Marx. Trata-se apenas de uma sumária exposição dos seus artigos A burguesia e a contra revolução, datados de 10 a 31 de dezembro de 1848, que fizeram parte dos seus escritos no jornal Nova Gazeta Renana. Dada a riqueza de conteúdos dos supracitados artigos, dentre eles selecionamos a concepção negativa da política, tentando resgatar os lineamentos que identificam tal concepção. Dessa forma, dividimos esta exposição em três partes: a primeira introduz a posição política de Marx no referido jornal; a segunda parte trata dos artigos propriamente ditos, na qual procuramos apresentá-los citando trechos principais que indicam o assunto tratado cujo fundamento se encontra nas considerações da terceira parte, com destaque à crítica de Marx ao pensamento político de Hegel.

PALAVRAS-CHAVE: Político. Estado. Propriedade privada. Liberdade. Universalidade abstrata.

\section{RESUMEN}

Este texto en sí no discurre sobre la concepción de la política en Marx. Es una breve exposición de sus artículos La burguesía y la contrarrevolución, datados del 10 al 31 de diciembre de 1848, que formaron parte de sus escritos en el diario Nueva Gaceta Renana. Debido a la riqueza de contenidos de los citados artículos, seleccionamos entre ellos la concepción negativa de la política, intentando rescatar los lineamientos que identifican tal concepción. Así, dividimos esta exposición en tres partes: la primera parte introduce la posición política de Marx en el mencionado periódico; la segunda parte trata de los artículos propiamente dichos, en la que procuramos presentarlos citando fragmentos principales que indican el asunto tratado cuyo fundamento se encuentra en las consideraciones de la tercera parte con destaque a la crítica de Marx al pensamiento político de Hegel.

PALABRAS CLAVE: Política. Estado. Propiedad privada. Libertad. Universalidad abstracta.

\footnotetext{
* Doutora em Educação, Mestre e Graduada em Filosofia. Professora de Filosofia da Universidade Federal do Ceará. Membro permanente do Programa de Pós-Graduação em Educação e em Filosofia da UFC. E-mail: fatimanobreufc@gmail.com.

** Doutor em Educação, Mestre e Graduado em Filosofia. Professor de Filosofia da Universidade Federal do Ceará. Membro efetivo do Programa de Pós-Graduação em Educação e do Programa de Pós-Graduação em Filosofia da UFC. E-mail: adautoufcfilosofia@ gmail.com.
} 


\section{INTRODUÇÃO}

Embora não apareça de forma sistematizada em um ensaio ou obra, a concepção negativa da política no pensamento de Marx está expressa nos vários passos de sua análise do regime capitalista cujo ponto culminante é o Estado - instrumento principal das contradições sociais e da perpetuação da hegemonia dominante.

A configuração dessa concepção já se anuncia desde os seus escritos no jornal Gazeta Renana (1842) - e depois na Nova Gazeta Renana (1848) - em que Marx inicia sua vida política, lançando-se na luta contra o absolutismo prussiano e os seus defensores ideológicos. Assim, os seus artigos neste jornal, embora poucos, devido à censura prussiana, já demonstram a sua concepção democrática e revolucionária, e o referido jornal torna-se o porta-voz das opiniões oposicionistas de toda a Alemanha.

A própria censura aos seus artigos servia-lhe como crítica, argumentando que "as leis que punem o modo de pensar, apenas podem ser promulgadas por um governo que se crê possuidor exclusivo da sabedoria política e que se opõe ao povo" (MARX apud FEDOSSEIEF et al., 1983, p. 34-35). Esse governo só pôde apoiar-se na máquina burocrática do Estado representado por arrogantes e onipotentes por meio dos quais o regime existente consagrava todos os atos e intervenções. Era esse o vício característico de todo o sistema político prussiano.

Ao publicar uma série de artigos sobre o Landtag Renano ${ }^{1}$ Marx começava a compreender que não só o Landtag, mas todo o Estado agia em favor dos proprietários privados: "O Estado na Prússia se rebaixa ao ponto de ser ativo, não à sua maneira, mas à maneira da propriedade privada". (MARX apud FEDOSSEIEF et al., 1983, p. 41). Nessa perspectiva Marx percebe que o Estado não é o porta-voz dos interesses de toda a humanidade, como o admitia Hegel, e sim apenas de uma parte desta - a classe dominante. Apesar de não ter uma posição ainda bem definida sobre a questão do Estado, o trabalho no jornal enriqueceu a sua experiência nesse campo, "tornou-se para ele claro que o Estado não é de modo nenhum a encarnação da sabedoria universal, como pretendia Hegel, que não é a encarnação do universal que domina os interesses particulares." (FEDOSSEIEF et al., 1983, p. 46). Essa é a pedra angular da concepção negativa da política posto que não há, de fato,

\footnotetext{
${ }^{1}$ Landtag Renano - Instituição de Estados, tipicamente feudal, em que dominava a nobreza. Marx atacou severamente o seu caráter antipopular em vários artigos, entre eles: Debates a propósito da lei sobre os roubos da madeira, justificação do correspondente do Mosela, debates sobre a liberdade de imprensa, e outros.
} 
uma defesa dos direitos de todos. Ao contrário, há aqui um ponto essencial: a ligação entre os interesses da propriedade privada e a política do Estado existente.

\section{A POSIÇÃO POLÍTICA DE MARX NO JORNAL NOVA GAZETA RENANA}

Ao criticar a natureza antipopular do Estado prussiano e ao impregnar nos artigos do jornal a ideia da sua iniquidade, Marx nega dessa forma toda a política aí existente. A partir daqui se verifica uma configuração dos componentes estruturais de sua concepção política que se intensificará posteriormente - cujo alvo principal será a supressão do instrumento pelo qual uma determinada classe mantém o poder — o Estado ${ }^{2}$. Essa "admissão da extinção do Estado implica numa reconcepção da política, que é a sua definição negativa". (CHASIN, 1986, p. 226, grifo do autor). Portanto, desde suas expressões mais antigas, “[...] a concepção marxiana da política é negativa, e por maiores que tenham sido as modificações ao longo dos seus escritos, a definição negativa da política permaneceu". (CHASIN, 1984, p. 49).

Vale repetir, a Gazeta Renana foi o prelúdio desse pensamento marxiano, no entanto, há uma série de elementos e obras que assinalam o pensamento posterior de Marx cujo ponto desencadeador foi a miséria alemã, principalmente o período das revoluções de 1848 a 1849 . Nessa fase, juntamente com a criação da Nova Gazeta Renana (31/05/1848) ocorre o "seu engajamento pessoal na prática política direta" (CHASIN, 1982, p. 57), em que ele extrai os pontos principais que consolidará a sua teoria revolucionária, política e social. Sem dúvida, os materiais da Nova Gazeta Renana sempre foram considerados pelos seus seguidores "como um momento da mais alta relevância prática e teórica de sua herança política e intelectual" (CHASIN, 1982, p. 57).

O referido jornal tentava aglutinar o conjunto das forças democráticas para a eliminação da monarquia e unificação da Alemanha em República. Porém não se tratava apenas de um órgão da democracia e sim de um instrumento orientador e organizativo a fim de levar a classe trabalhadora a uma autonomia política ao mesmo tempo em que se daria a decadência ideológica da burguesia reinante. Por aí se passava toda uma visão crítica da concepção idealista da sociedade e, simultaneamente, as descobertas das vias de transformação da ordem existente. A Nova Gazeta Renana era o único órgão de imprensa da época - não só na Alemanha como em toda a Europa - que fazia uma análise crítica e cien-

\footnotetext{
${ }^{2}$ Importante frisar que não se trata, no caso, da supressão do Estado enquanto organização social, e sim a supressão do Estado que é instrumento de dominação e que oprime os menos favorecidos.
}

Sapere aude - Belo Horizonte, v. 9 - n. 18, p. 142-160, jul./Dez. 2018 - ISSN: 2177-6342 
tífica dos principais acontecimentos referentes à revolução alemã e europeia em geral. $\mathrm{O}$ jornal educava as massas e unia, de maneira orgânica, a luta consequente pelos verdadeiros interesses nacionais do povo alemão ao internacionalismo proletário, "apoiava vigorosamente qualquer movimento de massas revolucionárias, fosse qual fosse o país em que se verificasse, desmascarava os seus inimigos, arrancava a máscara aos seus falsos amigos" (FEDOSSEIEF et al., 1983, p. 192-193).

Apesar de o jornal ter o subtítulo de Órgão da Democracia a sua bandeira não era uma democracia "à moda burguesa" e sim revolucionária. No entanto, a necessidade histórica do momento era apegar-se ao movimento burguês, às reivindicações burguesas, e deles tirar os frutos necessários à revolução proletária. Diz Engels (1985, p. 184-185):

O proletariado alemão apareceu, em primeiro lugar, na cena política como partido
democrático mais extremo [...] Por isso, quando fundamos na Alemanha um grande
jornal, nossa bandeira não podia ser senão a da democracia, mas a de uma
democracia que por toda, em cada caso, acentuava o caráter especificamente
proletário que ainda não podia inscrever, de uma vez por todas, no seu estandarte. Se
o não quiséssemos fazer, se não quiséssemos aderir ao movimento na sua ponta que
mais progredira, efetivamente proletária, já existente, e impulsioná-lo para adiante,
não nos restava senão ensinar comunismo numa pequena folhinha de província e em
vez de um grande partido de ação fundar uma pequena seita.

Eis o caráter da "Nova Gazeta Renana e o significado de ter sido subtitulado como o órgão da democracia" (CHASIN, 1982, p. 64). A Alemanha era o palco das lições políticas de Marx, e o jornal era o instrumento pelo qual explicitava essas lições cuja tarefa imediata era a derrubada do Estado prussiano e austríaco para unir toda a Alemanha numa República democrática, bem como uma guerra czarista $^{3}$, incluindo a reconstituição da Polônia. Essa exigência era o ponto principal sem o qual não poderia realizar-se a conquista do poder pela classe trabalhadora. Os acontecimentos da revolução francesa eram os órgãos de direcionamento dessa intenção. Dessa forma, Marx estudou não só o caso alemão, mas também observou de perto a situação social e política da França e Inglaterra. A partir de uma base real e crítica, ele pode avaliar o anacronismo social e político da Alemanha e perceber as contradições do seu próprio país e, ao fazê-lo, criticava ao mesmo tempo a estrutura da sociedade capitalista em geral.

Os seus artigos A burguesia e a contra-revolução, contidos no jornal Nova Gazeta Renana, retratam todo o processo alemão de março a dezembro de 1848 , por meio dos quais ele mostra principalmente a fragilidade da burguesia alemã que mesmo antes de triunfar o

\footnotetext{
${ }^{3}$ Marx via no czarismo russo o baluarte principal da reação europeia de então.
} 
absolutismo feudal já encontrara à sua frente a classe trabalhadora. Aqui a objetivação do capital se dá de uma forma atrasada denominada por Lênine de "Via prussiana", portanto, "o drama da revolução alemã de 48 é a tragédia da via prussiana" (CHASIN, 1982, p. 63). Fazendo um balanço dessa situação Engels (1985, p.184) faz o seguinte comentário:

\begin{abstract}
Os eventos de fevereiro em Paris $^{4}$ precipitaram a revolução alemã iminente e modificaram, com isso, o seu caráter. A burguesia alemã, em vez de vencer pela sua própria força, venceu a reboque de uma revolução operária francesa. Ainda antes de ter definitivamente derrubado os seus velhos adversários - a realeza absoluta, a posse fundiária feudal, a burocracia, a pequena burguesia cobarde - teve logo que fazer frente a um novo inimigo: o proletariado [...] Aterrorizada não com o que o proletariado alemão ${ }^{5}$ era, mas com aquilo em que ele ameaçava tornar-se e com o que o proletariado francês já era, a burguesia só viu salvação em um compromisso mesmo o mais cobarde, com a monarquia e a nobreza.
\end{abstract}

Os supracitados artigos sintetizam toda essa problemática nos quais Marx desenha o quadro alemão e revela as mazelas da burguesia que, embora fracassada, utiliza-se da política do Estado prussiano para colocar-se e manter-se no poder. Paralelamente analisa a situação social e política da França que resultara na sua negação da parcialidade política, ou seja, baseado no exemplo francês, mais tarde Marx dirá que uma revolução apenas política não é suficiente para exaurir as contradições do capitalismo, e sim uma revolução social.

Vale salientar a afirmação de José Chasin (1982) de que os artigos A burguesia e a contra-revolução, de modo especial, como o conjunto dos artigos de Marx publicados na Nova Gazeta Renana, de maneira geral, constituem, em sua obra, um momento privilegiado da tematização das formas particulares da objetivação do capitalismo, designadamente daquela que foi consagrada sob a expressão leniniana de via prussiana.

Em conformidade com isso são determinadas, em sua diversidade, as formas de dominação correspondentes [...] Para tanto, Marx, à medida que vai levantando armando o edifício conceitual, que determina o que, em seu tempo, chamou de miséria alemã, paralelamente configura a expressão clássica do capitalismo, resultante de uma revolução de tipo europeu (inglesa, francesa). Em suma, $A$ burguesia e a contra-revolução exibe a universalidade do capitalismo se realizando sob duas de suas formas particulares, mostrando suas diferenças, potencialidades e irrealizações (CHASIN, 1982, p. 65).

\footnotetext{
${ }^{4}$ Referente à Revolução Francesa de fevereiro (1848) em que os operários parisienses puseram fim a Monarquia francesa e proclamaram a Republica (nota nossa).

${ }^{5}$ O proletariado alemão, assim como a burguesia alemã, era proporcionalmente pouco desenvolvido, "crescido em completa servidão espiritual, desorganizado e nem sequer capaz de uma organização autônoma, possuía apenas o sentimento vago de sua profunda oposição de interesses contra a burguesia" (ENGELS, 1985, p. 184, nota nossa).
} 
Desta forma a Nova Gazeta Renana acompanha não só o movimento alemão, mas também todo o movimento europeu a partir do qual Marx desenvolve certos princípios que constituem o ponto de partida metodológico de sua concepção negativa da política e que desenvolverá em obras posteriores.

\section{A BURGUESIA E A CONTRA-REVOLUÇÃO}

Antes de entrarmos nos supracitados artigos convém mencionar a situação alemã da época. A Alemanha de 1848 caracterizava-se por um manifesto anacronismo: havia feito uma revolução apenas no plano das ideias, enquanto que econômica e politicamente encontrava-se às margens da sociedade moderna. A sua filosofia não passava de uma justificação ideológica destinada a rnanter uma situação política já ultrapassada, em virtude das revoluções realizadas em outros países, principalmente Inglaterra e França. A Alemanha de então era o resultado do Antigo Regime e o seu status quo não passava de um anacronismo, uma vez que ela apenas conhecia as restaurações das revoluções inglesa e francesa, sem, no entanto, ter feito revolução. Marx (1977, p. 02-04) já denunciara esse caráter anacrônico da Alemanha na introdução à Crítica da filosofia do direito de Hegel:

Se quisermos nos ater ao status quo alemão, embora apenas do único modo
adequado, ou seja, de modo negativo, o resultado continuaria sendo um anacronismo
[...] Nós, alemães, compartilhamos das restaurações das nações modernas sem que
tenhamos participado de suas revoluções [...] Na Alemanha começa-se por onde se
está terminando em França e Inglaterra [...] Enquanto em França e Inglaterra o
problema é: economia política ou império da sociedade sobre a riqueza, na
Alemanha é economia nacional ou império da propriedade privada sobre a
nacionalidade. Em França e Inglaterra trata-se, portanto, de superar o monopólio que
chegou até suas últimas consequências na Alemanha, trata-se, por outro lado, de
levar até suas últimas consequências o monopólio. Este é um exemplo suficiente da
forma alemã dos problemas modernos, um exemplo de corno nossa história, qual um
recruta desajeitado, tivesse até agora apenas como tarefa o exercício de imitar
histórias triviais.

É manifesto o atraso político e econômico da Alemanha nessa passagem de Marx. Paralelo a isso, ele critica igualmente a filosofia alemã que, embora sendo a sua única contemporaneidade, é, ao mesmo tempo, a única que sustenta a sua falácia, uma vez que se trata de uma filosofia abstrata, incompatível com a realidade alemã. Para Marx, a filosofia alemã do direito e do Estado é a única história alemã que se encontra ao nível do presente oficial moderno. 
Em política os alemães pensaram o que os outros povos fizeram [...] A Alemanha não galgou simultaneamente com os povos modernos as fases intermediárias da emancipação política [...] A Alemanha só acompanhou com a atividade abstrata do pensamento o desenvolvimento dos povos modernos, sem chegar a tomar parte ativa nas lutas reais deste desenvolvimento [...] O sonho utópico para a Alemanha não é a revolução radical, não é a emancipação humana geral, mas pelo contrário, a revolução parcial, a revolução meramente política, a revolução que deixa em pé os pilares do edifício. (MARX, 1977, p. 06-10).

Em virtude dessa situação ocorre a fragilidade da burguesia alemã que não fez revolução e, portanto, não estava em condições de se opor ao regime feudal absolutista e defender os seus interesses econômicos. Nestas condições ela só viu uma saída: a conciliação ilusória com a Coroa; o que proporcionou não uma mudança efetiva da sociedade e sim modificações - principalmente no terreno das ideias do direito - que serviriam apenas para restaurar e manter o velho sistema.

Dessa forma, partindo de uma análise histórica concreta, Marx pode verificar que a efetivação do processo de mudança não se dá a partir do jurídico ou do político e sim da revolução radical. Daí por que nos textos A burguesia e a contra-revolução Marx caminha o tempo todo para o homem social, demonstrando que a essência do ser humano não é política e sim social. O seu conteúdo gira em torno desse elemento ontológico: a instauração e transformação do ser social. Portanto, o seu terreno não é o jurídico e sim o revolucionário e o social. Aqui ele já demarca a universalidade de sua formulação teórica, cujo ponto de partida é a praxis revolucionária tendo como fim alcançar a emancipação humana geral e não simplesmente proclamar direitos abstratos que beneficiam apenas uma parte da população sob a égide de uma falsa universalidade ${ }^{6}$.

Nesse sentido, O "Ministério Camphausen"7 ${ }^{7}$ se apresenta como o grande mistificador da história ao estabelecer a supremacia de uma universalidade abstrata - através do terreno

\footnotetext{
${ }^{6}$ Marx já menciona na Crítica da Filosofia do Direito - Introdução (1977) que na emancipação política como ocorrera na França, a burguesia representou (superficialmente) a classe universal da sociedade, sendo sentida e reconhecida como tal, porém em prol dos seus próprios interesses. Mas para isso ela necessitou do seu representante negativo que era o clero e a nobreza; estas classes - que condicionaram o significado positivo da burguesia - são os elementos essenciais para que haja uma revolução parcial, das quais a Alemanha carece: "Qualquer das classes particulares da Alemanha carece da consequência, rigor, arrojo e intransigência capazes de transformá-la no representante negativo da sociedade. Tampouco possui estamento algum aquela grandeza de alma que se identifica, mesmo momentaneamente, com a alma do povo, nem aquela genialidade que infunde ao poder material o espírito do poder político" (1977, p. 11). Dessa forma a possibilidade positiva da emancipação alemã reside no proletariado - a classe capaz de dissolver todos os estamentos particulares da sociedade; a classe que "só pode recuperar a si mesma através da recuperação total do homem" (p.13). Marx mostra aqui a necessidade do poder político da classe trabalhadora através de uma revolução social, única via de emancipação efetiva do homem. Tudo isso vai se evidenciando durante as revoluções de 1848 e 1849.

${ }^{7}$ Primeiro ministério após a insurreição de março em Berlim, denominado por Marx de ministério de mediação, constituído principalmente pelos representantes da oposição burguesa, entre eles "Camphausen" que se tornou presidente do Gabinete Prussiano.
} 
jurídico - pois, ao recompor uma articulação com a coroa - contra o povo - estabeleceu um poder autocrático ainda maior que o anterior:

\begin{abstract}
Este Camphausen que inventou a teoria ententista ${ }^{8}$ para salvar o terreno jurídico [...], inventou ao mesmo tempo as minas que deveriam fazer saltar aos ares o terreno jurídico e a teoria ententista [...] Ele deixou em vigor a velha legislação prussiana sobre os crimes políticos e os antigos tribunais continuaram a funcionar. Sob seu governo a antiga burocracia e o antigo exército ganharam tempo para se recuperar do pânico e se reconstituírem completamente. Sem sofrer qualquer prejuízo, todos os chefes do antigo regime conservaram seus postos [...] E tudo isto sob os auspícios do grande Camphausen, do pensador amigo da história, do paladino do grande debate, do herói da conciliação. (MARX; ENGELS, 1982, p. 67-68).
\end{abstract}

Marx intensifica então a mistificação da universalidade sob o Ministério Camphausen que não fez mais que converter o interesse particular (o interesse da burguesia) num fantasioso princípio geral - "O princípio jurídico". Não nos enganemos, diz Marx: "não atribuamos a um Camphausen, a um Hanseman", a estes homens de pequeno porte uma iniciativa de estatura histórico-universal. Eles não foram nada além do que os órgãos de uma classe [...], não foram mais que a burguesia - no primeiro plano” (MARX; ENGELS, 1982, p. 68-69). O Ministério Camphausen não era o verdadeiro representante do povo, pois, em lugar de apoio às forças vitoriosas (após a insurreição de março), formulou um quadro jurídico de conciliação entre a Coroa e a Burguesia. Aqui está o desvio histórico fatal: a burguesia alemã não fizera uma revolução porque não destruiu o Antigo Regime como ocorrera nas revoluções inglesa e francesa. Era preciso que a burguesia reivindicasse sua parte na gestão política, ainda que apenas fosse pelos seus interesses materiais.

Tinha que tirar das mãos de uma burocracia ultrapassada, tão ignorante quanto arrogante, a administração dos seus interesses mais sagrados. Tinha que reclamar para si o controle da riqueza nacional, da qual ela se acreditara a criadora. Tinha também a ambição de conquistar uma posição política correspondente à sua posição social. Para alcançar seu objetivo tinha que poder debater livremente seus interesses e opiniões, bem como os atos do governo. É a isto que ela denominou "direito de livre associação". Tinha que reclamar a "liberdade religiosa" e outras igualmente, consequência necessária da "livre concorrência". E antes de março de 1848 a burguesia estava em excelente caminho para realizarem-se todos os seus desejos [...] Mas, para fazer oposição à Coroa era necessário fazer o corte ao povo. Face a face com o governo ela não poderia naturalmente reivindicar os direitos e liberdades às quais ela aspirava, a não ser que se apresentasse sob a razão social dos direitos e liberdades do povo. (MARX; ENGELS, 1982, p. 69-70).

\footnotetext{
${ }^{8}$ Referente à conciliação da burguesia com a Coroa (nota nossa).

${ }^{9}$ Membro do Gabinete Prussiano (nota nossa).
} 
Daí por que a revolução de março de 1848 não foi uma revolução burguesa e sim uma semi-revolução manifestada por um movimento popular docemente iludido pela oposição liberal burguesa. Diz Marx (1982, p. 70): "A burguesia prussiana havia sido alçada à cumeeira do Estado, mas não como ela o havia desejado [...], pois fora um movimento popular que lhe havia aberto o caminho. A burguesia não havia movido um dedo". Simplesmente havia permitido ao povo que lutasse por ela. Donde o poder que assim lhe foi entregue não era o poder do general que derrota seu adversário, mas o de um comitê de salvação pública ao qual o povo confia a defesa de seus próprios interesses.

A burguesia alemã deveria tomar o poder da aristocracia feudal - aproveitando-se dos cofres vazios do Estado prussiano - mas ela não o fez. Com uma economia mal estruturada e com o proletariado já à sua frente, a burguesia covardemente não viu outra saída que travar uma "aliança ofensiva e defensiva com a reação"; tornando-se assim um obstáculo na via revolucionária, caracterizando-se como antirrevolucionária. Aqui está a sua diferença das revoluções inglesa e francesa: enquanto estas transformaram efetivamente a sociedade, aquela não fez mais que conservar e reforçar o Antigo Regime - o absolutismo feudal.

Marx faz uma brilhante análise dessa distinção, ao mesmo tempo em que tira conclusões teóricas fundamentais sobre essas particularidades da revolução burguesa. Diz ele (MARX; ENGELS, 1982, p. 71):

\footnotetext{
É necessário não confundir a revolução de março nem com a revolução inglesa de 1648, nem com a revolução francesa de 1789. Em 1648 a burguesia aliada à nova nobreza, lutou contra a monarquia, a aristocracia feudal e o poder da Igreja. Em 1789 a burguesia, aliada ao povo, lutou contra a monarquia, a nobreza e a Igreja estabelecida. Nas duas revoluções a burguesia era a classe que verdadeiramente encabeçava o movimento. As revoluções de 1648 e de 1789 não foram a revolução inglesa e a revolução francesa, foram revoluções de tipo europeu. Elas não foram a vitória de uma classe particular da sociedade sobre o antigo sistema político, mas a proclamação de um sistema político para a nova sociedade europeia. Elas foram o triunfo da burguesia, mas triunfo da burguesia era então o triunfo de um novo sistema social [...] Não houve nada disso na revolução de março na Prússia [...] Bem longe de ser uma revolução europeia, ela não foi senão o eco debilitado de uma revolução européia, num país retardatário.
}

Percebe-se aqui que a revolução burguesa, na Ingleterra e na França, não promoveu apenas modificações de caráter econômico e/ou político e sim uma transformação efetiva da sociedade. Para que houvesse uma revolução burguesa na Alemanha, era preciso suprimir os restos do feudalismo e abrir caminho ao capitalismo como acontecera na Inglaterra e França. Marx mostra então que o evento de março na Alemanha não teve significação histórica 
nenhuma; enquanto que a Inglaterra e a França, principalmente, manifestaram-se como a cabeça da processualidade histórica.

\begin{abstract}
Para a Europa a revolução de março na Prússia era uma estrela em miniatura - era, aliás, urna miniatura em tudo -; sua radiação era a do cadáver de uma sociedade há muito tempo decomposta [...] A burguesia alemã tinha evoluído com tanta indolência, covardia e lentidão que, no momento ern que se ergueu ameaçadoramente em face ao feudalismo e do absolutismo, percebeu diante dela o proletariado ameaçador. Ela tinha não somente detrás dela a hostilidade de uma classe, mas diante dela a de toda a Europa, que a olhava com hostilidade [...] Sem fé nela própria, sem fé no povo, sem uma missão histórico-mundial - tal qual um ancião maldito, debilitado pela idade, ela se via condenada a dirigir e a desviar, em seu próprio benefício, as primeiras manifestações de juventude de um povo robusto -- Sem olhos! Sem ouvidos! Sem dentes! Sem nada! É assim que a burguesia prussiana se encontrou, depois da revolução de março, ao leme do Estado prussiano. (MARX; ENGELS, 1982, p. 72-73).
\end{abstract}

Dessa forma, aliar-se à reação foi a sua "tábua de salvação" que logo a naufragaria. Marx sublinha, então, as mazelas da teoria ententista, cujo ânimo não passava de um bloqueio à revolução. A teoria ententista não era de maneira nenhuma uma teoria oca; ao contrário, ela havia crescido sobre a árvore dourada da vida. A revolução de março, de maneira nenhuma, submeteu o soberano por direito divino ao povo soberano, ela somente obrigou a Coroa, o Estado Absolutista, a se entender com a burguesia, sua velha rival. A Coroa sacrificaria a nobreza à burguesia, a burguesia sacrificaria o povo à Coroa. "É sob esta condição que a monarquia se tornará burguesia e que a burguesia se tornará monárquica." (MARX; ENGELS, 1982, p. 73). Depois de março não há mais do que estas duas forças. "Elas servem alternadamente de pára-raios contra a revolução. Tudo naturalmente sobre a mais ampla base democrática [...] Era o segredo da teoria ententista".

Com o poder nas mãos a burguesia acreditara seriamente em sua entente com a Coroa. O único obstáculo era "o povo e a revolução" que ela severamente passou a atacar. "A revolução era o protesto do povo contra a entente da burguesia com a Coroa. A burguesia, entendendo-se com a Coroa protestava, pois, forçosamente contra a revolução. A revolução foi o título jurídico do povo" (MARX; ENGELS, 1982, p. 74).

A contrarrevolução foi reforçada ainda mais no segundo ministério depois da revolução de março: "O Ministério de Ação", o Ministério "Hansemann, ${ }^{10 "}$ que teria que transformar a resistência passiva ao povo em uma resistência ativa contra o povo. Esse

\footnotetext{
${ }^{10}$ Hansemann: Ministro das finanças, membro do gabinete anterior, permanecendo no seguinte. O Governo Camphausen havia sido substituído pelo aristocrata liberal Auerswald, porém Hansemann continuava a exercer um papel importante no "Ministério de Ação".
} 
segundo ministério fora fortemente marcado pela insurreição de junho em Paris ${ }^{11}$ da qual Marx extrai elementos importantes, mostrando a sua influência nos destinos da Alemanha. Em 26 de junho, “o ministério Hansemann se apresentou diante da Assembléia Nacional. Mas foi em julho que ele começou a existir seriamente. A revolução de junho estava no pano de fundo do ministério de ação, como a revolução de fevereiro esteve no pano de fundo do ministério de mediação" (MARX; ENGELS, 1982, p. 77). Em sua aridez de coração e estreita visão, os pequeno-burgueses alemães se tomaram pela burguesia francesa. $\mathrm{O}$ ministério Hansemann se considerava como um ministério da revolução de junho. Marx apresenta então, ironicamente, o resumo do programa desse ministério (1982, p. 77):

\begin{abstract}
Modificação das situações essenciais, incompatíveis com a Nova Constituição, liberação da propriedade dos vínculos que obstaculizam sua mais vantajosa exploração, numa grande parte da monarquia, reorganização da administração judiciária, reforma da legislação fiscal, notadamente a supressão das taxas de isenção etc., e, sobretudo, o fortalecimento do poder público, necessário à proteção da liberdade adquirida (pelos burgueses) contra a reação (uso da liberdade no interesse dos feudais) e a anarquia (uso da liberdade no interesse do povo) para a restauração da confiança perdida.
\end{abstract}

A "restauração da confiança perdida" era, pois, dirigida ao povo - a primeira necessidade proclamada pelo ministério Hansemann. Aqui os autores destacam (1982, p. 78) o que era dito pela boca de Hansemann: "repressão de todo movimento político no interior do proletariado e no de todas as camadas sociais cujos interesses não coincidam exatamente com os interesses da classe que, segundo sua opiníão, se acha no governo do Estado". Marx denuncia então a ilusão desse pretenso ministério que, ao trair o povo, colocou contra si próprio a reação feudal - esta não tardaria a restaurar o "estado de coisas" de antes de março. Bem junto à restauração da confiança perdida, dizem:

Hansemann colocou, pois, o fortalecimento do poder público. Mas ele se enganou simplesmente quanto à natureza deste poder [...] Ele queria ser avarento com os custos de produção da dominação burguesa e sobrecarregou a burguesia com as somas exorbitantes que custou a restauração da feudalidade prussiana [...] Ele queria

\footnotetext{
${ }^{11}$ Em fevereiro de 1848, os operários parisienses haviam proclamado a República Francesa, no entanto a burguesia contrarrevolucionária havia traído os seus interesses. Em virtude disto, entre 23 e 26 de junho, a massa proletária lançou-se na luta armada contra o atentado de sua conquista. A palavra de ordem dos insurretos era: instauração de uma "República Democrática e Social", porém foram esmagados pela superioridade numérica da burguesia. Após esta derrota a contrarrevolução passou a "atacar" em toda a Europa, exercendo, inclusive, forte influência na Alemanha. Marx avaliou esse acontecimento francês como sendo a primeira guerra civil entre a burguesia e o proletariado; o que custou caro à própria burguesia, uma vez que custou-lhe a derrocada das ilusões de fevereiro, ao desmascarar o seu próprio lema: "Liberdade, Igualdade, Fraternidade". A esse respeito Marx e Engels dizem que (1981a, p. 43): "os operários parisienses foram esmagados pelas forças superiores de seus inimigos, porém não se entregaram a elas. Estão derrotados, mas seus adversários foram vencidos”.
} 
fortalecer o poder público não somente contra a anarquia, quer dizer, contra o povo, mas também contra a reação, ou seja, contra a Coroa e os interesses feudais, na medida em que tentassem impor-se às custas do bolso e das pretensões políticas, as mais essenciais, isto é, as mais modestas da burguesia. (MARX; ENGELS, 1982, p. 78).

Definindo o caminho percorrido pelo Ministério de Ação, Marx mostra que as medidas "ofensivas" foram levadas a sério: numerosos processos contra a imprensa; numerosas prisões; a criação, em Berlim, de um corpo de polícia civil armada; o estado de sítio; reforço da velha polícia, da burocracia e do exército prussianos. Estas e outras ocorrencias foram o que caracterizou tal programa, e, sob o véu abstrato do poder burguês, a repressão do velho Estado foi reforçada. "Esse ministério e a Assembléia dos ententistas não representavam nada além do que o velho Estado burocrático e policial rebocado. A isto veio juntar-se o ressentimento contra a burguesia" (1982, p. 80); principalmente por parte do campesinato cujos interesses ela havia traído. Com isso ela perdera esse aliado principal.

O egoísmo miserável, medroso, insensível cegava a burguesia prussiana a tal ponto que ela repeliu seu aliado indispensável - o campesinato. A burguesia francesa começou pela emancipação dos camponeses. Com os camponeses ela conquistou a Europa. A burguesia prussiana estava embaraçada nos seus interesses mais imediatos e mesquinhos, que ela própria desperdiçou esse aliado e fez dele o instrumento nas mãos da contra-revolução feudal. (MARX; ENGELS, 1982, p. 82).

A impotência desse ministério, portanto, estava assinalada. Com o fortalecimento do poder público, com a elevação das taxas sobre a beterraba açucareira e aguardente, com a supressão de todas as isenções relativas aos impostos fundiários e o repúdio ao campesinato, essas e outras medidas forneceram subsídios à reação feudal que, encorajada com a traição da burguesia aos "seus aliados", não custou a restaurar a ordem em que a Alemanha se encontrara, antes dos acontecimentos de março. Marx assinala essa situação demonstrando a influência da revolução europeia na revolução alemã, principalmente no que se refere aos acontecimentos que levaram à decadência da burguesia prussiana.

\footnotetext{
A burguesia prussiana explorou contra o povo a vitória sangrenta da burguesia de Paris sobre o proletariado parisiense, da mesma forma como a Coroa prussiana explorou contra a burguesia a vitória sangrenta dos Croatas em Viena. As desgraças da burguesia prussiana, depois do novembro austríaco, são um ajuste de contas das desgraças do povo prussiano depois do junho francês. Os pequeno-burgueses alemães não pressentiram que, após o junho francês, haveria o novembro austríaco e que depois do novembro austríaco, um dezembro prussiano estava emboscado. (MARX; ENGELS, 1982, p. 77).
} 
Os acontecimentos decisivos dessa emboscada ocorreram sob o ministério Brandenburg, após a demissão do governo Auerswald-Hansemann. A começar pela transferência da Assembleia Nacional de Berlim para Brandenburg, depois dissolução e, finalmente, o "Golpe de Estado" em que o rei outorga a Constituição sem consultar qualquer assembléia. "Através desta Constituição a Coroa autorga novos privilégios — a ela mesma, bem entendido" (MARX; ENGELS, 1982, p. 84). Em apenas um parágrafo Marx resume a impotência da representação burguesa na sua tarefa (p. 83):

\footnotetext{
Sob o ministério Brandenburg a Assembléia Ententista foi ignominiosarnente dispensada, desdenhada, ridicularizada, humilhada, perseguida e no momento decisivo, o povo ficou indiferente. A derrota da Assembléia era a derrota da burguesia prussiana, dos constitucionalistas, portanto, uma vitória do partido democrático, qualquer que seja o preço que teve de pagar.
}

Marx conclui que a Alemanha era incapaz de fazer uma revolução política, uma vez que não havia uma conciliação possível entre as classes - que a compunham - capaz de transformá-las em representante universal da sociedade como ocorrera com a burguesia francesa. A partir dos acontecimentos da Prússia, de março a dezembro de 1848, Marx sintetiza as perspectivas da revolução na Alemanha ao considerar que a história da burguesia prussiana de março a dezembro, como a da burguesia alemã em geral, prova que na Alemanha "uma revolução puramente burguesa e o estabelecimento da dominação burguesa, sob a forma da monarquia constitucional, são impossíveis: só são possíveis a contra-revolução feudal absolutista ou a revolução republicana e social" (MARX; ENGELS, 1982, p. 84).

Ressaltando, na Alemanha a burguesia carecia de espírito de generalização e de fervor revolucionário - o que impedia a realização de uma revolução política. Daí porque, segundo Marx, só há estas duas perspectivas: a vitória da contrarrevolução feudal absolutista na qual permaneceria o velho Estado, os velhos privilégios, as velhas opressões, ou a revolução social na qual a soberania popular seria efetiva: não legalizaria interesses particulares, por meio de uma universalidade abstrata, e sim alcançaria a emancipação humana geral.

\section{A CRÍTICA DE MARX A CONCEPÇÃO HEGELIANA DO ESTADO}

Retomemos os pontos principais por onde passa a formulação do pensamento políticorevolucionário de Marx. Já dissemos que o seu prelúdio se deu no ano de 1842 ao criticar a natureza antipopular do Estado prussiano nos seus poucos artigos da Gazeta Renana e, 
posteriormente, nos artigos da Nova Gazeta Renana. Aqui Marx já enriquece a sua experiência em relação à questão do Estado, verificando que este não era a expressão da vontade geral como o admitia Hegel. A partir daí um problema latente se pôs a Marx: a concepção hegeliana do Estado como conciliador dos interesses gerais é puramente idealista. Dessa forma, a análise de Marx referente à filosofia hegeliana é, ao mesmo tempo, uma análise crítica do Estado Moderno, é, pois, a crítica da realidade política. Daí por que era preciso refutar Hegel na sua filosofia política, e Marx o fez na sua obra, entre outras, Crítica da filosofia do direito de Hegel cujo problema central reside na relação entre o Estado e a Sociedade Civil. Segundo Hegel, o Estado é um organismo acima da sociedade civil, determinando-a. Diz Marx (1983, p. 139 e 153): "Hegel não pretende que o Estado político seja determinado pela sociedade civil, mas sim que seja aquele a determiná-la. Hegel fez da causa efeito e do efeito causa, do determinante o determinado e do determinado o determinante." Portanto, ao contrário de Hegel, para Marx a sociedade civil é premissa do Estado que, ao invés de ser a expressão harmônica da sociedade, constitui sim, um produto das contradições sociais, manifestadamente na sociedade moderna.

É assim que os ideólogos burgueses, amparados pela filosofia política de Hegel, pretendem glorificar o Estado moderno como sendo o órgão de conciliação das classes, o que Marx vai refutar, pois a existência da divisão de classes é a manifestação das contradições no seio do próprio Estado, portanto, “longe de suprimir estas diferenças, o Estado só existe pela sua pressuposição" (MARX, 1978a, p. 19).

Será preciso, pois, suprimir esta forma de organização política — o Estado — para que reine a verdadeira igualdade social. "E isto implica numa reconcepção da política, que é a sua definição negativa" (CHASIN, 1986, p. 226, grifo do autor). Pode-se afirmar, então, que o ponto de partida de todo o pensamento marxiano é, em certo sentido, uma reflexão sobre o Estado e a sua dimensão negativa. Nele Marx detecta as mazelas do poder burguês e procura suprimir a existência desse poder. Nesse sentido, ao mencionar a questão da política, ele se refere a sua uma tematização social, em que a política é apenas um meio, e não um fim, para que se possa realizar a emancipação humana. "Em suma, à política só cabem as tarefas negativas ou preparatórias; a obra de regeneração, de que fala Marx, fica a cargo inteiramente da revolução social" (CHASIN, 1984, p. 51, grifo do autor).

A concepção política de Marx é, portanto, uma concepção negativa - nos parâmetros do capitalismo - e é expressa desde o início de sua reflexão teórica. "A miséria alemã foi, decerto, o ponto desencadeador desta visão [...] A crítica da política de Hegel é o passo 
subsequente [...] Por fim, são os próprios limites da política francesa que consolidam sua concepção negativa da política" (CHASIN, 1984, p. 49, grifo nosso).

A partir daí ficou claro que o Estado é a expressão do poder político e da divisão de classes, notadamente no sistema capitalista. A sua função (do Estado) tem sido, portanto, um órgão para manter o poder dos mais fortes e oprimir os mais fracos.

Os acontecimentos durante os anos de 1848 e 1849 na Europa vieram comprovar, pela prática, essa formulação teórica de Marx e acrescentar-lhe pontos importantes tais como: a necessidade de uma revolução social e a consciência, que os operários ganharam, de sua missão histórica. Nesse aspecto, as ideias políticas, as questões de estratégia e de tática adquiriram uma primordial importância.

Nos textos A burguesia e a contra-revolução Marx deixa claro que o poder político é, na verdade, o poder organizado de uma classe para a opressão de outras. Mesmo na Alemanha onde o Estado ganhou a aparência de uma autonomia, não deixou de exercer essa função. Como mostra claramente uma passagem de um dos textos, em que Marx afirma que o Ministério hanseniano "não representava nada além do que o velho Estado burocrático e policial rebocado [...] ele reforçou a polícia, esta derradeira expressão do antigo Estado, e a pôs em ação.” (MARX; ENGELS, 1982, p. 80). Dessa forma, o Estado é a expressão fundamental do poder político que tende a perpetuar-se em cada revolução. Mais tarde Marx dirá que "todas as revoluções aperfeiçoaram esssa máquina [do Estado], ao invés de destroçála" (MARX, 1978b, p. 396).

Para Marx, portanto, o poder político é a expressão da sociedade moderna em que, no desenvolvimento do capitalismo, a burguesia faz valer os seus interesses por meio do Estado. Esse pensamento ele já expressa, na Ideologia alemã, juntamente com Engels (1984, p. 97 98):

\footnotetext{
[...] através da emancipação da propriedade privada em relação à comunidade, o Estado adquire uma existência particular, ao lado e fora da sociedade civil; mas este Estado não é mais do que a forma de organização que os burgueses necessariamente adotam, tanto no interior como no exterior, para a garantia recíproca de sua propriedade e de seus interesses [...] Como o Estado é a forma na qual os indivíduos de uma classe dominante fazem valer seus interesses comuns e na qual se resume toda a sociedade civil de uma época, segue-se que todas as instituições comuns são mediadas pelo Estado e adquirem através dele uma forma política.
}

Para simplificar, pode-se afirmar então que, na prática, o Estado não é o que a ideologia burguesa defende. Na sua existência o povo é frustrado dos seus direitos, embora 
afirmados na filosofia hegeliana. Dessa forma, o Estado não resolve as contradições que nele se projetam, pelo contrário conserva e afirma essas contradições.

Hegel considera o Estado como elemento de certa racionalidade universal e absoluta. O Estado burguês tem a pretensão de ser mesmo esse universal, mas não passa de um Estado político e, como tal, é o instrumento de dominação de uma classe particular. Daí por que essa concepção do Estado se manifesta apenas como uma justificação ideológica do Estado burguês, que surgiu como uma ilusória conciliação entre o homem público e privado; porém, na verdade, não passa de sua cisão.

A solução dessas contradições não estaria no plano político e sim no plano social, pois o Estado moderno, capitalista, para Marx é apenas um fenômeno histórico e tende a desaparecer. Apesar de sua importância "a emancipação política não é a forma absoluta e total da emancipação humana" (MARX, 1978a, p. 16). Isso só pode ocorrer com a revolução social e a consequente tomada do poder político pelo proletariado, que, gradativamente, será extinto (o poder político burguês) por não ser mais necessário. "Em vez, pois, da antiga sociedade burguesa com suas classes e consequentes conflitos, surge um novo tipo de sociedade na qual o desenvolvimento social de todos se condiciona ao livre desenvolvimento de cada um" (MARX; ENGELS, 1981b, p. 36).

As contradições da sociedade burguesa, portanto, levam historicamente à sua eliminação, como afirma Marx (1978c, p. 130): "As relações burguesas de produção constituem a última forma antagônica do processo social de produção". No entanto as próprias forças produtivas que se encontram em desenvolvimento no seio da sociedade burguesa criam, ao mesmo tempo, as condições materiais para a solução desse antagonismo, "com esta formação social se encerra a pré-história da sociedade humana" (MARX, 1978c, p. 130).

\section{CONSIDERAÇÕES FINAIS}

Retomando algumas considerações, podemos dizer que as revoluções de 1848/1849 foram uma brilhante escola que consolidou a concepção negativa da política no pensamento de Marx, ao mesmo tempo em que instaurou a sua teoria política e revolucionária. Portanto, o reforço da necessidade da revolução social se deu a partir da Alemanha, tomando como paradigma a situação da Inglaterra e França, onde o capitalismo se desenvolveu de forma mais efetiva, com uma participação ativa da burguesia. Por conseguinte, as revoluções inglesa e 
francesa foram o referencial clássico da objetivação do capitalismo, no entanto não foram as formas decisivas da emancipação humana e sim apenas importantes para a descoberta das vias revolucionárias.

A partir dessas considerações, Marx vai perceber que uma revolução apenas política não é suficiente - como no caso francês - ela é um aspecto parcial da totalidade do processo social. É preciso, portanto, que na sua essência a revolução seja social, apesar de ser um ato político, para que se rompa a "interdependência entre sociedade civil e Estado tendo o capital como centro organizativo de ambos" (CHASIN, 1984, p. 49). A revolução social, para Marx, visa remover a contradição entre parcialidade e universalidade que as revoluções políticas do passado sempre produziram, submetendo a sociedade em seu complexo ao domínio da parcialidade política, em benefício dos setores dominantes da sociedade civil. Desse modo, a revolução deve romper com o círculo vicioso no sentido de que a sociedade civil, estruturada pelo domínio do capital e da propriedade privada, termina por garantir a dominação do Estado político burguês e esse, por sua vez, garante o domínio sobre o conjunto da sociedade. A concepção negativa da política no pensamento de Marx rompe com esse círculo e com o poder dominante, voltando-se para o social e para a emancipação humana. Em síntese, a política é a forma de sustentação do Estado e este é a "flor venenosa" da sociedade civil; um perpetua a existência do outro, o que mantém a dominação política de uma classe sobre outra e, consequentemente, as contradições sociais.

Reforçando: "o específico da concepção negativa da política incide precisamente sobre a ruptura [...]" (CHASIN, 1986, p. 226) desse estado de coisas. Esse é um dos critérios centrais para a extinção do poder de uma classe que se volta apenas para os interesses do capital e da propriedade privada. A partir daqui há uma possibilidade, mesmo que latente, de uma emancipação humana social e não apenas política. Esta, como diz Marx (1977): “deixa em pé os pilares do edifício".

Trazendo essas considerações para a atualidade, podemos afirmar que, embora o capitalismo atual tenha uma roupagem diferente daquela do tempo de Marx, permanece a mesma lógica de dominação e dos interesses privados expressos hoje na chamada economia de mercado. E isso tanto em termos globais como em termos do Brasil, principalmente em relação aos últimos acontecimentos da política econômica e/ou governamental. Vivemos hoje uma situação política de extrema sensibilidade, e cada vez mais se expressa a necessidade da luta por uma igualdade na desiguladade do capitalismo que consiste, principalmente, na defesa de uma economia de mercado marcada pelo Estado Neoliberal em defesa da livre 
concorrência e da privatização de bens e serviços estatais. Tudo produzido pela iniciativa privada de caráter nacional e internacional. Portanto, as análises de Marx não perderam o vínculo com a atual realidade e nos faz recuperar os seus desdobramentos trazendo para o momento presente as suas contribuições no sentido de voltarmos a pensar e/ou continuarmos a pensar na luta em torno da emancipação humana.

Sabemos que são várias as interpretações das concepções de Marx, algumas às vezes até mesmo diferentes do seu pensamento, porém mutatis mutandis é preciso ter claro que a luta pela emancipação ainda se faz necessária, ainda que no seio do próprio capitalismo. Repetimos: isso remete à concepção negativa da política no sentido de negar o Estado unilateral que atende exclusivamente aos interesses de uma economia de mercado e que tem em vista a privatização dos serviços sociais. Decorre, então, a necessidade de um Estado no qual as contradições não sejam escamoteadas e que seja voltado realmente para o social. Aqui remete a um ato político, porém trata-se de um Estado com uma alma social. A verdadeira democracia deve ser uma mediação para essa consecução, por conseguinte, ela deve estar voltada para os deveres e direitos sociais na perspectiva da emancipação humana.

\section{REFERÊNCIAS}

CHASIN, J. A burguesia e a contra-revolução - Apresentação: Marx e a Revolução Alemã de 1848. In: Revista Ensaio. $1^{\text {a }}$ ed., São Paulo: Editora e Livraria Escrita Ltda., 1982, n. 10, p. $56-65$.

CHASIN, J. Democracia política e emancipação humana. Revista Ensaio. $1^{a}$ ed., São Paulo: Editora Ensaio Ltda., 1984, n. 13, p. 47-55.

CHASIN, J. Poder, política e representação. Revista Ensaio. São Paulo: Editora Ensaio Ltda., 1986, n. 15/16, p. 225-232.

ENGELS, Friedrich. Revolução e contra-revolução na Alemanha. In: Obras escolhidas. Lisboa: Avante, 1982, p. 310 - 412. Vol. I.

ENGELS, Friedrich. Marx e a Nova Gazera Renana In: Obras escolhidas. Lisboa: Avante, 1985, p. 182-191. Vol. III.

FEDOSSEIEF. O. N. e outros. O caminho para o materialismo e para o comunismo e no período das revoluções de 1848-1849. In: Karl Marx: Biografia. Tradução do Instituto de Marxismo-leninismo. Lisboa: Avante, 1983. p. 14 - 61 e 177 - 246.

LÉNINE, V. I. O estado e a revolução. In: Obras escolhidas. Lisboa: Avante, 1978, Vol.II, p. 219-305. 
MARX, Karl. Crítica da filosofia do direito de Hegel. In: Temas de ciências humanas. Tradução de José Carlos Bruni e Raul Mateus Castell. São Paulo: Editorial Grijalbo, 1977, n. 2, p. $01-14$.

MARX, Karl. A questão judaica. Tradução de João Fagundes. $2^{a}$ ed. Lisboa: União Ltda, 1978a.

MARX, Karl; ENGELS, Friedrich. O 18 Brumário de Luís Bonaparte. In: Marx. Tradução de Leandro Konder e Edgar Malagodi. 2a ed., São Paulo: Abril Cultural, 1978b, p. 329-404. (Os Pensadores).

MARX, Karl; ENGELS, Friedrich. Para a Crítica de Economia Política - Prefácio. In: Marx Os Pensadores. Tradução de Leandro Konder e Edgar Malagodi. $2^{a}$ ed., São Paulo: Abril Cultural, 1978c, p. 127-132.

MARX, Karl. Crítica da filosofia do direito de Hegel. Tradução de Conceição Jardim e Eduardo Lúcio Nogueira. $2^{a}$ ed. Lisboa: Presença Ltda., 1983.

MARX, Karl; ENGELS, Friedrich. A burguesia e a contra-revolução (dezembro-1848).

Revista Ensaio. Tradução de J. Chasin e Maria Dolores Prades. São Paulo: Editora e Livraria Escrita Ltda., 1982, n. 10, p. 67-90.

MARX, Karl; ENGELS, Friedrich. A relação do estado e do direito com a propriedade. In: A Ideologia alemã. Tradução de José Carlos Bruni e Marco Aurélio Nogueira. $4^{a}$ ed., São Paulo: HUCITEC, 1984, p. 96-101.

MARX, Karl; ENGELS, Friedrich. La revolucion de junio. In: Marx e Engels. Sobre la revolucion de 1848/1849 - Articulos de "Neue Rheinische Zeitung". Moscú: Editorial PROGRESSO, 1981a, p. 43-48.

MARX, Karl; ENGELS, Friedrich. O manifesto do partido comunista. $2^{a}$ ed., São Paulo: Global Editora, 1981b. 